УдК 352.001

\author{
H. B. Мішина
}

\title{
ПРИНЦИП СУБСИДІАРНОСТІ ТА ОРГАНИ САМООРГАНІЗАЦІї НАСЕЛЕННЯ В УКРАЇНІ
}

Варто зазначити, що нині в українській юридичній літературі існує неабиякий інтерес до принципу субсидіарності (від лат. subsidiarius допоміжний). Він пов'язаний із низкою успіхів України на шляху європейської інтеграції. Проте також інтерес до принципу субсидіарності пов'язаний із тим, що він є парним із принципом єдності публічної влади. Зв'язок між цими принципами є настільки тісним, що А.Є. Баньковський навіть пропонує вести мову про принцип єдності й субсидіарності державної влади. Проте він слушно визначає, що субсидіарність передбачає додатковість, взаємодопомогу та наближеність до населення публічно-владних органів [1].

Характеризуючи сутність принципу субсидіарності, Г.З. Біккулова зазначила, що вона полягає в органічному сполученні двох ціннісних начал (свободи й солідарності), взятих у розумних межах і співвідношеннях, та підкреслила, що досвід європейської політичної інтеграції свідчить про те, що практична реалізація принципу субсидіарності можлива в певному соціокультурному контексті, що передбачає готовність учасників процесу до узгодження загальних і приватних інтересів [2]. Однак вважаємо, що під приватними інтересами автор мала на увазі власні інтереси органів публічної влади різного рівня, між якими відбувається передача повноважень.

У зв'язку із цим дослідження всіх аспектів реалізації, у тому числі можливої реалізації принципу субсидіарності в Україні, є доречним та актуальним питанням сучасної юридичної науки.

Проблеми, пов'язані з практичною реалізацією принципу субсидіарності в Україні, досліджували П.М. Любченко, В.В. Таболін, Д.В. Красіков та інші вчені. Варто виділити розробки О.С. Орловського та О.В. Прієшкіної, у яких запропонована дефініція терміна «органи самоорганізації населення». Однак проблематика практичної реалізації принципу субсидіарності в Україні шляхом активізації функціонування органів самоорганізації населення знайшла своє втілення вперше в цій публікації. 
Метою статті є аналіз перспектив практичної реалізації принципу субсидіарності в Україні на місцевому рівні шляхом активізації функціонування органів самоорганізації населення.

Принцип субсидіарності нині є досить популярним принципом конституціоналізму як в Україні, так і в зарубіжних країнах, а також на наднаціональному рівні (на рівні Європейського Союзу (далі - ЄС)). Це пов'язано 3 його універсальністю: він може застосовуватись для врегулювання відносин між наднаціональними органами ЄС і державами-членами, між державними органами та органами суб'єктів федерації, між державними органами та органами місцевого самоврядування тощо. К.В. Ентін стверджує: «Головне призначення принципу субсидіарності - визначення, на якому рівні має прийматись рішення в тій чи іншій сфері. У його основу покладено ідею, згідно з якою акти мають за можливості прийматись на максимально наближеному до населення рівні (регіональному чи державному). Однак це не означає, що принцип субсидіарності покликаний оберігати компетенцію держав-членів; він має на увазі перед прийняттям будь-якого акта необхідність проведення аналізу ефективності з огляду на масштаби й передбачувані результати, щоб виявити оптимальний рівень вчинення дій» 3, с. 35-36]. Д.В. Красіков вважає: «Принципом субсидіарності є правило, згідно з яким організація вищого рівня бере на себе відповідальність за виконання будь-яких функцій тільки в тому випадку, якщо організація нижчого рівня не в змозі це зробити» [4, с. 33].

Тому варто ще раз наголосити, що принцип субсидіарності має парний принцип. Як зазначають дослідники, для реалізації концепції «доброго управління» ці два принципи повинні гармонійно доповнювати один одного (мова йде про «принцип належної централізації» (солідарність) і «принцип належної децентралізації» (субсидіарність) - H. М.) [5].

Якщо звернутись до законодавства України, то принцип субсидіарності поки що закріплено лише в Бюджетному кодексі України. У п. 7 ч. 1 ст. 7 цього акта вказано: «Принцип субсидіарності - розподіл видів видатків між державним бюджетом та місцевими бюджетами, а також між місцевими бюджетами грунтується на необхідності максимально можливого наближення надання гарантованих послуг до їх безпосереднього споживача» [6]. Таким чином, принци субсидіарності має дві складові частини адміністративну й фінансову. Активний розвиток цих двох складників принципу субсидіарності характеризує сучасну динаміку вдосконалення його змісту та поглиблення його сутності, а також сприяє полегшенню його практичної реалізації.

Однак кількість згадок про принцип субсидіарності в законодавстві не $є$ показовою. Варто погодитись із думкою Т. Шиллінга щодо того, що якщо брати до уваги субсидіарність серйозно, то це вимагає не тільки закріплення його в правовій нормі. $Є$ подальша необхідність розвивати цю норму [7]. Саме на цьому доцільно акцентувати увагу в подальшому викладі, а також розглянути цю проблему на прикладі взаємодії органів місцевого самоврядування та органів самоорганізації населення. 
«Примірюючи» принцип субсидіарності до місцевого рівня, П.М. Любченко зазначає: «Сутність цього принципу полягає в тому, що публічна влада повинна втручатись лише тією мірою й у тих межах, за яких суспільство та його групи (від індивідуумів до родини, територіальних громад та інших більш значних груп) не в змозі задовольнити свої різнобічні потреби. Таким чином, відповідно до принципу субсидіарності передавати повноваження від влади більш низького рівня до влади більш високого рівня дозволяється лише тією мірою, якою ці повноваження можуть бути краще здійснені на вищому рівні» [8, с. 119].

Щодо можливості застосування принципу субсидіарності на локальному рівні В.В. Таболін пише: «Визначаючи в статуті компетенцію органів самоврядування великого міста, варто керуватись принципом субсидіарності, без якого неможливе ефективне управління містом (урбанізованим регіоном)» $[9$, с. 17-18]. Тим самим учений приєднується до думки, що найнижчим рівнем застосування принципу субсидіарності $€$ не той рівень, який передбачає взаємодію між органами державної влади та органами місцевого самоврядування. Очевидно, що принцип субсидіарності, на його думку, може бути застосований також у межах адміністративно-територіальної одиниці - міста. В Україні одним із найбільш імовірних прикладів такого застосування $€$ взаємодія між органами місцевого самоврядування та органами самоорганізації населення.

Під час розгляду статусу органів самоорганізації населення як елемента системи місцевого самоврядування в Україні привертає увагу майже повна відсутність доктринальних досліджень цього інституту (винятки становлять деякі наші роботи $[10 ; 11 ; 12])$ та недостатній розвиток відповідної нормативно-правової бази. Наприклад, на сучасному етапі існує декілька нормативних визначень терміна «органи самоорганізації населення», причому одне визначення доповнює інше, проте жодне з них не $є$ повним i коректним. Вважаємо, що вирішення цього питання на науковому рівні сприятиме внесенню відповідних змін до законодавства, що у свою чергу позитивно вплине на динаміку створення нових і на ефективність функціонування існуючих органів самоорганізації населення - складової частини системи місцевого самоврядування в Україні.

На сучасному етапі в законодавстві України існують два визначення органів самоорганізації населення:

- представницькі органи, що створюються жителями, які на законних підставах проживають на території села, селища, міста або їх частин, для вирішення завдань, передбачених законом (Закон України «Про органи самоорганізації населення» від 11 липня 2001 р.);

- представницькі органи, що створюються частиною жителів, які тимчасово або постійно проживають на відповідній території в межах села, селища, міста (Закон України «Про місцеве самоврядування в Україні» від 21 травня 1997 р.).

На наше переконання, визначення терміна «органи самоорганізації населення» в зазначених нормативних актах має бути однаковим. У зв'язку 
із цим безумовно прийнятною є практика Верховної Ради України починати закони України зі статті, у якій надається термінологія відповідного акта. Проте, як у випадку із Законом України «Про органи самоорганізації населення» та Законом України «Про місцеве самоврядування в Україні», це досить часто призводить до того, що існують два чи більше визначень одного й того ж терміна.

Об’єднавши елементи наведених дефініцій, можна зробити висновок, що законодавець визначає органи самоорганізації населення як представницькі органи, що створюються частиною жителів, які на законних підставах тимчасово або постійно проживають на відповідній території в межах села, селища, міста або їх частин, для вирішення завдань, передбачених Законом України «Про органи самоорганізації населення».

Таке «об'єднане» визначення потребує конкретизації й уточнення; відповідні пропозиції містяться в доктринальних дефініціях, яких на сучасному етапі в Україні дві. О.В. Прієшкіна пропонує визначати органи самоорганізації населення як представницькі органи - частини територіальної громади, що утворюються згідно з рішенням ради, обираються загальними зборами громадян або їхніми представниками з ініціативи жителів населеного пункту, які тимчасово чи постійно проживають на відповідній території в межах села, селища, міста [13, с. 77]. Це визначення викликає декілька зауважень. По-перше, оскільки згідно з Конституцією України територіальна громада - це жителі села чи добровільного об'єднання в сільську громаду жителів декількох сіл, селища та міста, навряд чи можна вважати органи самоорганізації населення «частиною територіальної громади». По-друге, органи самоорганізації населення, як і передбачено їхньою назвою, утворюються за ініціативою жителів певної території, а не згідно з рішенням ради.

Більш коректною вважаємо дефініцію О.С. Орловського: «Органи самоорганізації населення - це представницькі органи, що створюються частиною жителів, які досягли вісімнадцятирічного віку, не позбавлені судом дієздатності та тимчасово або постійно проживають на відповідній території в межах села, селища, міста» [14, с. 261]. Однак це визначення є дещо перевантаженим унаслідок детального переліку осіб, які мають право ініціювати створення органів самоорганізації населення.

Крім того, жодне доктринальне визначення не містить вказівку на завдання, які виконують органи самоорганізації населення. Для усунення цього недоліку вважаємо за доцільне звернутись до норм Закону України «Про органи самоорганізації населення», який передбачає, що основними завданнями органів самоорганізації населення $€$ такі: створення умов для участі жителів у вирішенні питань місцевого значення в межах Конституції й законів України; задоволення соціальних, культурних, побутових та інших потреб жителів шляхом сприяння в наданні їм відповідних послуг; участь у реалізації соціально-економічного, культурного розвитку відповідної території, інших місцевих програм. Отже, замість відсильної норми «для вирішення завдань, передбачених Законом України «Про органи са- 
моорганізації населення», яка включена до доктринальної дефініції, можна застосувати фразу «для вирішення питань місцевого значення переважно соціального, економічного чи культурного характеру».

Що ж стосується права ініціювати створення цих органів, то Закон України «Про органи самоорганізації населення» передбачає, що воно може бути реалізоване «частиною жителів, які на законних підставах тимчасово або постійно проживають на відповідній території в межах села, селища, міста або їх частин». Більш детальний аналіз цього нормативного акта дає підстави стверджувати, що існує значно більше вимог. Це право мають такі громадяни України:

- які проживають у межах населеного пункту або його частини, якщо межі цієї території не співпадають із межами діяльності будь-якого органу місцевого самоврядування (беручи до уваги те, що місце проживання - це адміністративно-територіальна одиниця, на території якої особа проживає строком понад шість місяців на рік);

- яким на день відповідного волевиявлення виповнилось 18 років;

- які не визнані судом недієздатними;

- які не є військовослужбовцями строкової служби;

- які за вироком суду не перебувають у місцях позбавлення волі.

На підставі цього можна запропонувати визначати коло осіб, інтереси яких представляють органи самоорганізації населення, терміном «територіальний мікроколектив». Отже, особи, які мають право ініціювати створення органів самоорганізації населення, - це члени територіального мікроколективу, які за законодавством України мають право голосу на місцевих виборах.

Поняття «територіальний мікроколектив» (сукупність фізичних осіб, між якими існують відносно стійкі прямі соціальні зв'язки та які мають місце проживання на території відповідного населеного пункту, межі якої не співпадають із межами діяльності будь-якого органу місцевого самоврядування [15]) запропоновано нами за аналогією з терміном «територіальний колектив». Дефініція «територіальний мікроколектив» (мікрогромада) поки що не зустрічається в законодавстві.

Як висновок зазначимо про певний недолік у сприйнятті принципу субсидіарності в Україні: він розглядається як такий, що передбачає розподіл влади між органами публічної влади, тоді як під час звернення до одного з першоджерел (католицької доктрини) можна побачити, що «ідея субсидіарності в католицькому соціальному вченні демонструє принцип розподілу повноважень між державою та асоціаціями (групами добровольців) для характеристики багатьох взаємовідносин щодо проблем як особистості, так і загальнодержавного добробуту» [16, с. 54]. Отже, у національному розумінні принципу субсидіарності поки що немає альтернатив. I виникає логічне запитання: чому повноваження від органів державної влади передаються саме органам місцевого самоврядування, а не, скажімо, неурядовим організаціям? Чому не передбачена передача повноважень від органів місцевого самоврядування органам самоорганізації населення, хоча це логічно постає 
зі змісту принципу субсидіарності? Адже, наприклад, волонтери проявили себе з найкращого боку останнім часом в Україні, не кажучи вже про те, що ще в радянські часи було проведено багато досліджень, присвячених передачі функцій державних органів громадським організаціям.

Перспективи подальших розвідок у цьому напрямі полягають у подальшому дослідженні зв'язку між практичною реалізацією принципу субсидіарності та діяльністю органів самоорганізації населення в Україні.

\section{Література}

1. Баньковский А.Е. Принцип единства и субсидиарности в организации государственной власти Российской Федерации: конституционно-правовое исследование : дисс. ... канд. юрид. наук : спец. 12.00.02 «Конституционное право; муниципальное право» / А.Е. Баньковский ; Алтайский гос. ун-т. - Барнаул, 2013. - 223 с.

2. Биккулова Г.З. Принцип субсидиарности: идейно-теоретический смысл и европейские политические реалии : дисс. ... канд. полит. наук : спец. 23.00 .02 «олитические институты и процессы» / Г.З. Биккулова ; Казанский гос. эконом. ун-т. - Казань, 2000. - 191 с.

3. Энтин К.В. Право Европейского Союза и практика Суда Европейского Союза : Гучеб. пособие] / К.В. Энтин. - М. : НОРМА - ИНФРА-М, 2015. - 240 с.

4. Красиков Д.В. Юрисдикция Европейского суда по правам человека: принцип субсидиарности : дисс. ... канд. юрид. наук : спец. 12.00.10 «Международное право; европейское право» / Д.В. Красиков ; Саратовская гос. академия права. - Саратов, 2004. - 182 с.

5. The Principles of Solidarity and Subsidiarity [Електронний ресурс]. - Режим доступу : http:/ / www.inquisition.ca/en/polit/artic/solidarite.htm.

6. Бюджетний кодекс України : Закон України від 8 липня 2010 р. № 2456-VI / / Відомості Верховної Ради України. - 2010. - № 50-51. - Ст. 572.

7. Schilling T. Subsidiarity as a Rule and a Principle, or: Taking Subsidiarity Seriously / T. Schilling [Електронний ресурс]. - Режим доступу : http://www.jeanmonnetprogram.org/ archive / papers / 95/9510ind.html.

8. Любченко П.М. Муніципальне право України : [навч. посібник] / П.М. Любченко. - Х. : ФIHH, 2012. - 496 c.

9. Таболин В.В. Организационно-правовые основы деятельности органов местного самоуправления в крупных городах и урбанизированных регионах : дисс. ... докт. юрид. наук : спец. 12.00.02 «Конституционное право; муниципальное право» / В.В. Таболин ; Академия управления МВД России. - М., 1999. - 426 с.

10. Мішина Н.В. Конституційно-правове регулювання діяльності органів самоорганізації населення: порівняльно-правове дослідження : [монографія] / Н.В. Мішина. - О. : Друкарський дім, 2009. - 298 с.

11. Мішина Н.В. Органи самоорганізації населення: порівняльно-правове дослідження : дис. ... докт. юрид. наук : спец. 12.00.02 «Конституційне право; муніципальне право» / Н.В. Мішина ; Одеська нац. юрид. академія. - О., 2009. - 595 с.

12. Мішина Н.В. Органи самоорганізації населення: минуле, сучасне, перспективи : [монографія] / Н.В. Мішина. - О. : Вид-во ОРІДУ НАДУ, 2008. - 240 с.

13. Прієшкіна О.В. До питання про нормативне закріплення конституційно-правового статусу органів самоорганізації населення в Україні / О.В. Прієшкіна / / Часопис Київського університету права. - 2005. - № 2. - С. 73-78.

14. Орловський О.С. Правовий статус органів самоорганізації населення : дис. ... канд. юрид. наук : спец. 12.00.02 «Конституційне право; муніципальне право» / О.С. Орловський ; Одеська нац. юрид. академія. - О., 2004. - 265 с.

15. Мішина Н.В. До питання про класифікацію територіальних мікроколективів / Н.В. Мішина / / Актуальні проблеми державного управління: збірник наукових праць Одеського регіонального інституту державного управління. - 2006. - № 2. - С. 224-230.

16. Kondratiene V. Aspects of Legislative Governance of the State: the Principle of Subsidiarity as a Tool for Local Consolidation / V. Kondratiene / / Socialiniai tyrimai : Social Research. 2012. - № 3. - P. 53-61. 


\section{Ано о а ці я}

Мішина Н. В. Принцип субсидіарності та органи самоорганізації населення в Україні. - Стаття.

Статтю присвячено розкриттю перспектив практичної реалізації принципу субсидіарності в Україні на місцевому рівні шляхом активізації функціонування органів самоорганізації населення.

Ключові слова: субсидіарність, принцип субсидіарності, місцеве самоврядування, муніципальна реформа, органи самоорганізації населення.

\section{Ан н о т а ци я}

Мишина Н. В. Принцип субсидиарности и органы самоорганизации населения в Украине. - Статья.

Статья посвящена раскрытию перспектив практической реализации принципа субсидиарности в Украине на местном уровне путем активизации функционирования органов самоорганизации населения.

Ключевые слова: субсидиарность, принцип субсидиарности, местное самоуправление, муниципальная реформа, органы самоорганизации населения.

\section{S u m m a r y}

Mishyna N. V. Principle of subsidiarity and self-organized bodies of population in Ukraine. - Article.

This article highlights the perspectives of the principle of subsidiarity in Ukraine at the local level. The author sees perspective possibility of its practical realization in connection with the self-organized bodies of population.

Key words: subsidiarity, principle of subsidiarity, local government, municipal reform, self-organized bodies of population. 